\title{
Migration Movements in Varaždin in the Context of the Process of Modernization (1850 - 1918) with Special Emphasis on the Towns of Civil Croatia and Styria
}

The author compares migration movements in Varaždin in the period of modernization (1850 - 1918) with the largest towns of the Croatian area (Zagreb and Osijek) and Styria (Graz and Maribor). She reviews the power of centralization of urban area, the relations between natural and migratory movements of population, and their implication on the socio-economic and ethnic structure of population. Research results show that migrations in the Varaždin area were weaker in intensity due to Varaždin's peripheral position in the modernization process. This was caused by the absence of railway infrastructure, inadequate accumulation of capital and late industrialization. The proof of reversibility of socio-economic development (1857-1869) characterized by the beginning of industrialization, the ascent of urbanization, immigration ("nonnatives" accounted for $26.33 \%$ of the population) and the growth of total population by $18.32 \%$, followed by a period of economic stagnation $(1869-1880)$ which had a negative reflection on demographic movements (reducing the population number by $2.87 \%$ ). In the following decades, demographic movements were positive, but extremely slow, which had a low level of population mobility reconstructed upon information on nativeness and language: a large portion of the population was born in Varaždin and spoke Croatian as the mother tongue, with further tendencies of growth in the structure of total population. The relations between the natural and the migration movement of population in Varaždin during the first decade of the $20^{\text {th }}$ century indicate that population increased as the result of immigration which, given its low intensity, could not ensure significant demographic growth (between 1900 and 1910 the population of Varaždin increased by the modest 5.7\%). Population analysis by age and gender shows a decline of male population between the ages of 25 and 29 (working population), which was the subject of emigration movement directed mainly towards the rest of the Croatia and Central Europe. A comparison of statistics on emigration from Varaždin County and the town of Varaždin shows emigrational processes in the County to be of higher intensity and divergent in direction as the result of an agricultural crisis and overpopulation that comes with it, and was the product of the division of agricultural cooperatives. Obviously, the town of Varaždin and the rest of the Croatian area could not have absorbed the meagre part of the rural population of north-western Croatia which emigrated mainly to North America. 


\section{Introduction}

In Social Sciences the term modernization implies radical processes of social changes, that first emerged in western Europe already in the late Middle Ages, while their most intense form took place after the two major revolutions: the technological revolution in agriculture and industry during the $18^{\text {th }}$ and $19^{\text {th }}$ centuries, creating the necessary economic foundation of modernity (industrialization, urbanization, capitalism as a new form of appropriation and distribution, etc.), and the French Revolution of 1789, which provided the political and institutional framework of modernity (constitutionality, the rule of law, democratic order, the principle of sovereignty of nation-states etc.). ${ }^{1}$ Due to a variety of external and internal factors, these processes were very slow in Croatia (the beginnings of modernization date to the mid- $19^{\text {th }}$ century as the result of modernization efforts undertaken by Vienna) and uneven, particularly in terms of industrial production as the central urbanization element which greatly determined the intensity and direction of migration movements. It was in that context that the position of Varaždin as the modernization centre of north-western Croatia was analysed, along with migration movements which shaped its demographic structure in the second half of the $19^{\text {th }}$ and the beginning of the $20^{\text {th }}$ century. Due to the complexity of these processes, determining their dynamics and intensity requires a look at the broader context of issues mentioned; therefore, a comparative analysis was performed for Varaždin, the largest towns of Civil Croatia - Zagreb and Osijek and the largest towns of Styria - Graz and Maribor, chosen because of the comparability of their socioeconomic development and demographic trends at the beginning of the modernization period (except for Graz, which reached the level of urban development as established in central Europe in the second half of the $19^{\text {th }}$ century).

The term migration of population (mechanical movement) signifies spatial mobility of population..$^{2}$ It is a complex process which, along with the natural movement, represents part of the overall movement of population and causes a series of changes in its structure (demographic, socio-economic, ethnic and other). The complexity of migrations leads to different typologies and definitions which is why research in this study was focused primarily on migration in the strict sense, namely on moving from the place of permanent residence to the place of immigration for a longer period of time.

In addition to methods of historical demography, the basic research method applied in this study is the comparative analysis of censuses of $1851,1857,1869$,

ALLEN 2003: 403-410; MADDISON 2001: 19-24; BURKE 1993; KALANJ 1990: 10-13.

2 MACLEMAN 2014: 16-35; BAUER 2011: 449-474; KING 2010; CASTLES AND MILLER 2009; WERTHEIMER-BALETIĆ 1999: 281. 
$1880,1890,1900$ and $1910^{3}$ that provide comparable data for a longer period regarding the urban areas. Since the afore mentioned censuses did not collect data on ethnic and national structures, these structures were estimated based on data on place of origin, language and religion, which cannot ensure absolute exactness. As it turned out, it was virtually impossible to estimate the number of Croats and Serbs based on their mother tongue because they were classified together (Croatian or Serbian mother tongue) as well as based on their religious affiliation because of the heterogeneity of the category Orthodox (the problem of excluding members of other non-Serbian Orthodox nations: Romanians, Greeks, Bulgarians, Macedonians, Aromanians, the Roma and others) and Roman Catholics, but also because of the conflicting identification of respondents with regard to their religion and language. Likewise, there were statistical ambiguities considering Jews because of their linguistic heterogeneity; hence their number was assessed based on religion.

\section{Socio-economic structure of the population}

The dynamics of modernization processes in an area can be, to some extent, perceived by analysing the socio-economic structure of its population which can lead us to the perception of causes, intensity and direction of migration movements in that area. While studying statistical sources pertaining to this subject matter, data on the occupation of active population was taken into account. The main focus was on analysing occupations outside of agriculture as such analysis provides insight into the specific characteristics of modernization flows within certain towns.

According to the analysis of the economic structure of the Varaždin population in the late 1860s, a high percentage of population was engaged in agriculture (25.66\%), which is an indication of a slower economic development. Quantitative data show that Varaždin was an urban settlement of farmers and craftsmen, with a significant share of military population and attendance staff, an emerging sector of organized savings banks (the Varaždin savings bank ${ }^{4}$ became operational in February 1869 as the first banking institution in the Varaždin area, but it already went bankrupt in the late 1870s), and a negligible share of population working in the transport sector due to the lack of railway infrastructure. Compared to the national area, Osijek had the most dynamic economic structure, with a share of $5.58 \%$ of the total agricultural population. On the whole, however, economic development of the entire Croatian area could not compare with the development of

Statistical sources used in the paper are listed in the bibliography.

4 Varaždinska štedionica [The savings bank of Varaždin]. 1869. Pučki prijatelj. February $18^{\text {th }}$, 1869. 
Graz and Maribor, which, in the 1860s, had the characteristics of industrial towns - a low share of agricultural activities and guild crafts, over $20 \%$ of employees in industrial trades, the presence of the savings bank sector and a smaller percentage of population in the category of labourers and household servants (Table 1).

Table 1: Number and percentage of inhabitants in selected towns of Civil Croatia and Styria with regard to their main occupations in 1869

\begin{tabular}{|c|c|c|c|c|c|c|c|c|c|c|}
\hline $\begin{array}{l}\overrightarrow{0} \\
\vdots \\
\dot{s}\end{array}$ & 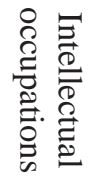 & 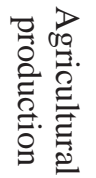 & 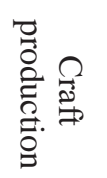 & $\begin{array}{l}\overrightarrow{1} \\
\stackrel{0}{0} \\
0\end{array}$ & 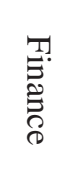 & $\begin{array}{l}\vec{B} \\
\stackrel{P}{9} \\
\stackrel{0}{0} \\
\stackrel{\infty}{\infty}\end{array}$ & 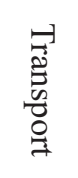 & 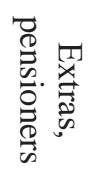 & 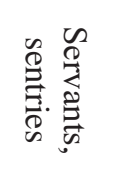 & 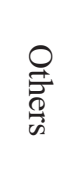 \\
\hline Graz & 5,836 & 2,866 & 3,485 & 2,575 & 755 & 17,597 & 755 & 7,965 & 12,200 & 19 \\
\hline$\%$ & 7.19 & 3.53 & 4.29 & 3.17 & 0.93 & 21.69 & 0.93 & 9.81 & 15.03 & 0.02 \\
\hline Maribor & 805 & 820 & 609 & 418 & 8 & 2,812 & 477 & 599 & 1,293 & 1 \\
\hline$\%$ & 6.24 & 6.36 & 4.72 & 3.18 & 0.06 & 21.82 & 3.7 & 4.64 & 10.03 & 0 \\
\hline Osijek & 906 & 430 & 2,314 & 495 & & & 168 & 387 & 2,610 & 398 \\
\hline$\%$ & 11.75 & 5.58 & 30.02 & 6.42 & & & 2.18 & 5.02 & 33.86 & 5.17 \\
\hline Varaždin & 646 & 1,435 & 1,281 & 242 & & & 8 & 406 & 1,255 & 319 \\
\hline$\%$ & 11.55 & 25.66 & 22.91 & 4.33 & & & 0.15 & 7.26 & 22.44 & 5.7 \\
\hline Zagreb & 1,868 & 1,553 & 2,660 & 518 & & & 86 & 670 & 3,507 & 263 \\
\hline$\%$ & 16.83 & 13.8 & 23.95 & 4.67 & & & 0.77 & 6.03 & 31.58 & 2.37 \\
\hline
\end{tabular}

Source: GROSS AND SZABO 1992: 70-72; Die Bevölkerung 1871: 32.

At the beginning of the $20^{\text {th }}$ century only slight changes were recorded in the economic structure of the population, keeping Varaždin on the margins of modernization processes which were underway in urban areas of Central Europe during the second half of the $19^{\text {th }}$ century. Agricultural production still had a high share (18.2\%), decreasing only slightly in the next decade (16.32\%). Continuous development of non-agricultural activities can be traced only in craft production which, in 1910, employed a third of the working population (Table 2).

Table 2. : The economic structure of the population of Varaždin (1900 - 1910)

\begin{tabular}{lllllll}
\hline Town & \multicolumn{5}{c}{ Number } & \multicolumn{5}{c}{ Percentage } \\
\hline Varaždin & 1900 & 1910 & Difference & 1900 & 1910 & Difference \\
\hline $\begin{array}{l}\text { Agricultural } \\
\text { production }\end{array}$ & 2,352 & 2,192 & -160 & 18.2 & 16.32 & -34.18 \\
\hline Mining & 8 & 3 & -5 & 0.06 & 0.02 & -1.07 \\
\hline Ind. crafts & 3,750 & 4,259 & 509 & 29 & 31.79 & 108.76 \\
\hline
\end{tabular}


Ivančica Jež - Migration Movements in Varaždin in the Context of the Process of Modernization...

\begin{tabular}{|c|c|c|c|c|c|c|}
\hline $\begin{array}{l}\text { Trade and } \\
\text { savings-bank sector }\end{array}$ & 820 & 897 & 77 & 6.34 & 6.7 & 16.45 \\
\hline Transport & 580 & 784 & 204 & 4.49 & 5.85 & 43.58 \\
\hline $\begin{array}{l}\text { Public service and } \\
\text { free occupations }\end{array}$ & 1,419 & 1,431 & 12 & 10.97 & 10.68 & 2.57 \\
\hline Soldiers & 1,626 & 1,449 & -177 & 12.58 & 10.81 & -37.82 \\
\hline Labourers & 347 & 450 & 103 & 2.68 & 3.36 & 22 \\
\hline Household servants & 719 & 595 & -124 & 5.56 & 4.44 & -26.49 \\
\hline Extras/ Pensioners & 594 & 648 & 54 & 4.59 & 4.84 & 11.54 \\
\hline Others & 715 & 690 & -25 & 5.53 & 5.15 & -5.34 \\
\hline Total & 12,930 & 13,398 & 468 & 100 & 100 & 100 \\
\hline
\end{tabular}

Source: SG II: 62; VRANJEŠ-ŠOLJAN 1991: 153.

However, the analysis of the structure of craft activities by the number of employees shows that a half of registered craft workshops operated without auxiliary work force, while the other half employed only a few of such workers. In 1900, there was just one company in Varaždin with more than 20 employees, employing a total of 41 workers. ${ }^{5}$ At the same time, 41 such companies existed in Zagreb, employing 3,665 workers and accounting for almost half of all employees in craft activities. The beginnings of electrification and industrialization in Varaždin date back only to the early $20^{\text {th }}$ century and the construction of an electric power station and the opening of the Schwarz, Zublin \& Co. Littai (Krain) \& Warasdin (Croatien) ${ }^{6}$ weaving shop and Count Lambert's furniture factories ${ }^{7}$; however, as both closed down rather quickly (the weaving shop operated from 1902 to 1909 and the furniture factory from 1903 to 1907), their influence on the socio-economic structure of the town's population was minor. In 1910, Varaždin had just four industrial enterprises with only 314 workers, which accounted for $0.49 \%$ of the employees in the craft-industrial activity. There were 79 such factories with 5,984 workers in Zagreb at that time (Table 3).

5 In this instance, there is the question of setting the criteria for distinguishing crafts and industrial enterprises. Milovan Zoričić, director of the Statistical Office in Zagreb, marked plants employing up to five workers as small industry, between six and twenty as medium industry, and more than twenty as large industries. Unlike the German craft statistics, which set the border between medium and large industries to fifty workers, Zoričić relied on the criteria of the Hungarian statistics, describing it as more appropriate for Croatian conditions. ZORIČIĆ 1896: 169-170. Modern historiography accepted five and twenty workers as elements for the classification of industrial enterprises on the Hungarian territory, provided that enterprises which employ more than twenty workers belong to factory production. STIPETIĆ 2012: 188-189; KARAMAN 1991: 170.

6 DAZG, 252, Trgovinska komora u Zagrebu, Sudbeni stol Varaždin, 157, Družtvene tvrtke.

7 DAZG, 252, Trgovinska komora u Zagrebu, Sudbeni stol Varaždin, 282, Inokosne tvrtke. 
Table 3: The structure of craft industry by the number of employees in selected towns of Civil Croatia (1900 and 1910)

\begin{tabular}{|c|c|c|c|c|c|c|c|c|}
\hline & & & & & $\begin{array}{c}>20 \\
\text { employees }\end{array}$ & & $\begin{array}{c}>20 \\
\text { employees } \\
(\%)\end{array}$ & \\
\hline Year & Town & $\begin{array}{l}\text { Com- } \\
\text { panies }\end{array}$ & $\begin{array}{c}\text { Em- } \\
\text { ployees }\end{array}$ & $\begin{array}{c}\text { Without } \\
\text { employees }\end{array}$ & $\begin{array}{l}\text { Compa- } \\
\text { nies }\end{array}$ & $\begin{array}{c}\text { Em- } \\
\text { ployees }\end{array}$ & $\begin{array}{c}\text { Compa- } \\
\text { nies }\end{array}$ & $\begin{array}{l}\text { Wor- } \\
\text { kers }\end{array}$ \\
\hline \multirow[t]{3}{*}{1900} & Varaždin & 767 & 900 & 409 & 1 & 41 & 0.13 & 4.55 \\
\hline & Zagreb & 2,344 & 7,511 & 1,080 & 41 & 3,665 & 1.79 & 48.79 \\
\hline & Osijek & 1,074 & 1,907 & 576 & 14 & 697 & 1.3 & 36.54 \\
\hline \multirow[t]{3}{*}{1910} & Varaždin & 801 & 1,341 & 415 & 4 & 314 & 0.49 & 23.41 \\
\hline & Zagreb & 2,979 & 10,985 & 1,445 & 79 & 5,984 & 2.65 & 54.47 \\
\hline & Osijek & 1,538 & 3,719 & 888 & 25 & 2,057 & 1.62 & 55.31 \\
\hline
\end{tabular}

Source: SG I: 501; SG II: 385-387.

Likewise, transport activities (4.49\% in 1900 and 5.85\% in 1910) were underrepresented given the importance of Varaždin's geographical location on the border between Hungary, the Styrian and the Croatian area (Table 2). The construction of railroads in the 1880s and 1890s (Čakovec - Varaždin - Zaprešić and Varaždin - Lepoglava - Golubovec) ${ }^{8}$, on account of their adjoining nature, did not bring the expected quantitative and qualitative changes in the socio-economic and demographic development of the town as it did in the case of Maribor in the 1860s.

At the beginning of the $20^{\text {th }}$ century over $10 \%$ of the population earned their livelihood by working in public services (Table 2). Due to its geo-strategic position, Varaždin was an important military stronghold throughout history, as evidenced by numerous military barracks in the town area. Town authorities regularly allocated certain/funding in the budget for their modernization in order to maintain the present military population in the town, the supply of which ensured the livelihood for a large number of the town's craftsmen, merchants and citizens. However, in the first decade of the $20^{\text {th }}$ century military forces located in the wider town area were noticeably downsized, being delegated to eastern border areas.

Compared to Varaždin, the early $20^{\text {th }}$-century Zagreb had the characteristics of an industrial town in which industrial production greatly surpassed that of the craftsmen. Its beginnings can be traced back to the 1870s and the construction of the railway that connected Zagreb with the main centres of the Monarchy, namely the branch of Southern railways between Zidani Most - Zagreb - Sisak (1862) and the section Budapest - Zagreb - Rijeka (1873), by which Zagreb

STULLI 1986: 1-78. 
became involved in the Monarchy's trade routes, ${ }^{9}$ and to the opening of credit institutions and joint stock companies for factory ventures with the participation of domestic and foreign capital: a steam-mill, several foodstuff establishments (the liqueur factory of Franjo Pokorni, vinegar, spirit and rose-brandy processing plants, breweries and others), two leather factories, a steam sawmill, a town gas plant and others. ${ }^{10}$ At the beginning of the $20^{\text {th }}$ century $8.09 \%$ of the population lived off agricultural production, while in 1910 this share decreased to $6.85 \%$, which was still a relatively high percentage in comparison to the leading cities in Central Europe. ${ }^{11}$ In 1900, Graz had 3.47\% of agricultural population, Vienna $1.19 \%$ and Prague $1.05 \%$. The percentage of population employed in the craftindustrial production in Zagreb was 32.68\%, while in Graz it was around $42 \%$, in Vienna over 55\%, and in Prague about 44\%. ${ }^{12}$ Likewise, comparative analysis of leading central European cities and Zagreb in the area of trade and finance, transport and public services shows that Zagreb significantly lagged behind these towns, and thus placing it on the periphery of the development in Central Europe.

The progressive development of Osijek during the second half of the $19^{\text {th }}$ and early $20^{\text {th }}$ century had an impact on the socio-economic structure of its population, as evident from the continuous decline in the share of farmers, which in 1910 amounted to $6.87 \%$, and from an increase in non-agricultural activities, particularly industrial production. The comparison of statistical information shows that the activities with impact on industrialization and urbanization (crafts, industry, trade, banking, transport and public services) secured the livelihood for $62.02 \%$ of the population of Osijek, almost $10 \%$ more compared to Varaždin in the same period. ${ }^{13}$ In the first decade of the $20^{\text {th }}$ century Osijek had the best structure of industrial production in the Croatian region. Just 25 industrial enterprises employed 2,057 workers, accounting for $55 \%$ of total employment in trade and industry (Table 3 ), a quarter of which worked in the match and sugar factories. An analysis of the structure of industry in Osijek shows the dominance of manufacturing (match factory, flour mill, glass factory, brewery, oil plant, sugar factories and others $)^{14}$ and its need for labour intensified migration movements.

When comparing the socio-economic development of Varaždin, Zagreb and Osijek, one can notice relative uniformity at the beginning of the modernization period which, with some exceptions, can be traced to the early 1860s when Varaždin

\footnotetext{
STULLI 1975: 129-144.

10 IVELJIĆ 2007: 133-150.

11 VRANJEŠ-ŠOLJAN 1991: 147.

12 Berufsstatistik 1904: 96-97.

13 VRANJEŠ-ŠOLJAN 1991: 180.

14 ŽIVAKOVIĆ-KERŽE 1996: 76-84.
} 
lost its progressive continuity of development which affected the dynamics of the socio-economic structure of its population (continuously high proportion of agricultural population and an extremely low proportion of industrial workers). Unlike Zagreb and Osijek, Varaždin failed to annul this discontinuity in development and it left significant marks on its demographic structure.

\section{Migrations - indicators of urbanization and industrialization}

The modernization efforts of Vienna during the 1850s, the power of centralization and Varaždin's previously mentioned prominent position in transport stimulated population growth. The most important cyclical period in the second half of the $19^{\text {th }}$ century was recorded between 1857 and 1869 when attempts were made to open new industrial plants within the town centre (tobacco in 1857, steam-mill in 1859 , steam sawmill in 1860 and chicory $)^{15}$, resulting in a demographic growth of $18.32 \%$ (Tables 4 and 5 , Chart 1).

Table 4: The number of inhabitants in selected towns of Civil Croatia and Styria (1851-1910)

\begin{tabular}{|c|c|c|c|c|c|c|c|}
\hline $\begin{array}{c}\text { Year } \\
\text { Towns } \\
\end{array}$ & 1851 & 1857 & 1869 & 1880 & 1890 & 1900 & 1910 \\
\hline Varaždin & 8,398 & 8,978 & 10,623 & 10,371 & 11,055 & 11,494 & 12,149 \\
\hline Zagreb & 14,258 & 16,657 & 19,857 & 29,218 & 38,742 & 57,698 & 74,703 \\
\hline Osijek & 13,221 & 13,883 & 17,247 & 18,201 & 19,778 & 23,018 & 28,505 \\
\hline Maribor & 6,850 & 6,294 & 12,882 & 17,628 & 26,154 & 24,601 & 27,994 \\
\hline Graz & 55,421 & 63,176 & 81,119 & 97,791 & 114,066 & 138,080 & 151,781 \\
\hline
\end{tabular}

Source: SG I: 4; SG II: 8-9; Bevölkerung 1859: 56; Bevölkerung 1882: 18; Volkszählung 1882: 812-813; Volkszählung 1890: 23; Volkszählung 1904: 20; Volkszählung 1912: 10.

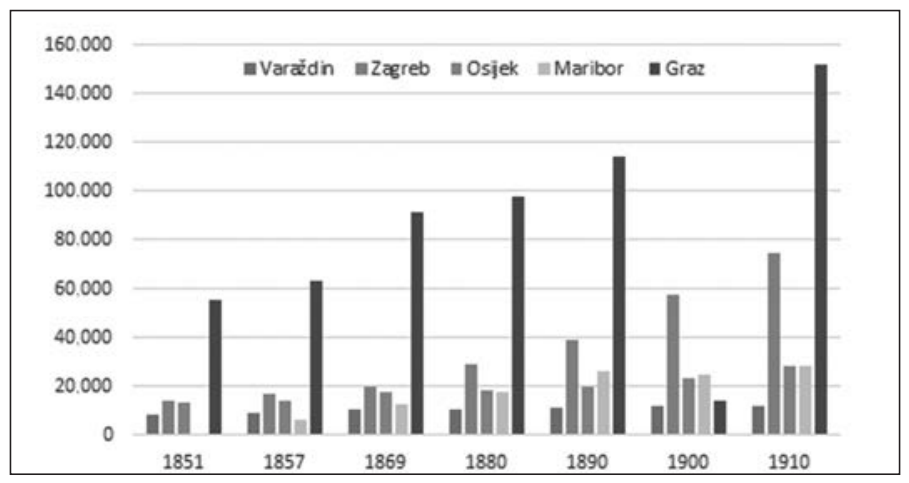

Chart 1: The number of inhabitants in selected towns of Civil Croatia and Styria (1851 - 1910)

15 DESPOT 1964: 120-123. 
Ivančica Jež - Migration Movements in Varaždin in the Context of the Process of Modernization...

Table 5: The percentage increase or decrease of the number of inhabitants in selected towns of Civil Croatia and Styria (1851-1910)

\begin{tabular}{ccccccc}
\hline Years & 1851 & $\begin{array}{c}1857- \\
1869\end{array}$ & $\begin{array}{c}1869 \\
-1880\end{array}$ & $\begin{array}{c}1880 \\
-1890\end{array}$ & $\begin{array}{c}1890 \\
-1900\end{array}$ & $\begin{array}{c}1900- \\
1910\end{array}$ \\
\cline { 1 - 5 } Towns & -1857 & 1869 & & & \\
\hline Varaždin & 6.9 & 18.32 & -2.87 & 6.6 & 3.97 & 5.7 \\
\hline Zagreb & 16.82 & 19.21 & 43.21 & 32.6 & 48.91 & 29.4 \\
\hline Osijek & 5 & 25.44 & 5.53 & 8.61 & 16.39 & 23.84 \\
\hline Maribor & -1 & 10.42 & 36.84 & 48.36 & -5.93 & 13.79 \\
\hline Graz & 14.02 & 28.4 & 17.6 & 16.64 & 21.05 & 14.75 \\
\hline
\end{tabular}

Source: The calculation based on information in Table 4.

The power of centralization was particularly prominent at the beginning of the period considered (1857 - 1869), when Varaždin proportionally had the highest share of "non-natives" in the total population (26.33\%, or 2,364 citizens). Half a century later, this share stood at only $4.3 \%$ as a result of adverse socio-economic trends in the town during the second half of the $19^{\text {th }}$ century. At the same time, the proportion of immigrants in Zagreb and Osijek in 1910, compared to 1857 , was on the rise (Table 6). This was the result of immigration, in particular of the Hungarian and German population in Osijek, and the strengthening of their administrative and political functions.

Table 6: The share of immigrants in total population of selected towns of Civil Croatia (1857 and 1910)

1857 Total Number of The 1910 Total Number of The

Towns population immigrants $\begin{gathered}\text { share of } \\ \text { immigrants }\end{gathered}$ Towns population immigrants share of

\begin{tabular}{cccccccc}
\hline Varaždin & 8,978 & 2,346 & 26.33 & Varaždin & 12,149 & 511 & 4.3 \\
\hline Zagreb & 16,657 & 4,263 & 25.6 & Zagreb & 74,703 & 366 & 28.73 \\
\hline Osijek & 13,883 & 1,686 & 12.4 & Osijek & 28,505 & 2,162 & 24.22 \\
\hline
\end{tabular}

Source: SG II: 57. For 1857, information taken from: VRANJEŠ-ŠOLJAN 2009: 86-87.

Positive development trends in Varaždin were brought to a stop by railway isolation, which was followed by the 1873 financial crisis in the Monarchy and the collapse of the town's finances at the end of the $1870 \mathrm{~s}$, leading to negative demographic trends and population decrease $(1869-1880)$ by $2.87 \%$. The last three decades of the period considered $(1880-1910)$ saw a positive but negligible growth $(1880-1890$ by $6.6 \% ; 1890-1900$ by $3.97 \% ; 1900-1910$ by $5.7 \%)$.

During the same period, Zagreb and Maribor recorded strong growth following the construction of railway infrastructure which stimulated the beginnings of 
industrialization and urbanization. In this sense, the demographic development of Maribor is indicative. The population of Varaždin during the 1850s outnumbered the population of Maribor by almost a third. After the construction of the ViennaMaribor - Ljubljana - Trieste railway (1846), the main traffic route of the Austrian part of the Monarchy, Maribor's geographical transit position changed, marking the beginning of the manufacturing phase of the town's industrial development $(1846-1918)$ and the first major "industrial reversal". ${ }^{16}$ The following branch lines were attached to that railway line: Pragersko - Čakovec - Budapest, Zidani Most - Zagreb - Sisak, Maribor - Dravograd - Klagenfurt, Špije - Radgona - Ljutomer, Celje - Velenje - Dravograd and Grobelno - Rogaška Slatina - Krapina. During this period, 43 factories and smaller plants were opened, and Maribor reached the highest industrial growth of all Slovenian towns, ${ }^{17}$ which was reflected in its demographic processes. Between the two censuses (1857-1869), Maribor's population doubled. This trend continued in the next two decades, up to the economic crisis in the $1890 \mathrm{~s}$, when its population decreased by almost $6 \%$. Renewed growth was seen in the first decade of the $20^{\text {th }}$ century (Table 5). Despite a significant demographic decline between 1890 and 1900, the population of Maribor doubled compared to Varaždin, which continued to fall behind throughout the $20^{\text {th }}$ century. According to the last census (2011), 38,839 inhabitants lived in the town centre, or 46,946 if suburbs are included. ${ }^{18}$ Table 4 shows that Zagreb reached the same level of urbanization already in the 1890s.

After the financial crisis in the early 1870 s, a new stage in the industrialization of Graz began with the founding of Österreichische Alpine Montangessellschaft (1881), which took over the majority of iron mines and began to concentrate the iron-processing industrial plants in its hands. The company built three factories in Graz in the 1890 s employing 1,400 workers at the end of the $19^{\text {th }}$ century. A sharp increase in production was recorded in the foodstuff processing, construction and metal industry. ${ }^{19}$ Great demand for labour in the 1880 s prompted migratory movements throughout the Monarchy. The largest number of immigrants came from Hungary $(6,106)$, Bohemia $(5,217)$, Carinthia $(3,660)$, Moravia $(2,340)$, Carniola $(2,083)$, Croatia and Slavonia $(1,024)$, their share in the total population reaching $33 \%$. At the same time, the share of immigrants in Maribor stood at $27.61 \%$. An

\footnotetext{
VODOPIVEC 2011: 9.

17 The number of industrial plants: $1869 \quad 1910$

Ljubljana $\quad 11 \quad 26$

Maribor $\quad 5 \quad 16$

Celje $\quad 0 \quad 7$

Source: LORBER 1999: 74.

18 http://www.dzs.hr/Hrv/censuses/census2011/results/htm/H01_01_03/h01_01_03zup05.html

19 SANDGRUBER: 1993: 275-295;VODOPIVEC 2011: 21.
} 
analysis of immigrants by gender shows that women were significantly involved in migration processes. Women accounted for $47 \%$ of all immigrants in Graz and $36 \%$ in Maribor (Table 7), indicating that immigration involved entire families.

Table 7: Present population regarding their birth place and gender in Graz and Maribor in 1880

\begin{tabular}{cccccccccc}
\hline Towns & Bohemia & Bukovina & $\begin{array}{c}\text { Dalmatia } \\
\text { and Istria }\end{array}$ & Galicia & Carinthia & Carniola & $\begin{array}{c}\text { Croatia } \\
\text { and } \\
\text { Slav. }\end{array}$ & $\begin{array}{c}\text { Aust. } \\
\text { Littoral }\end{array}$ & Moravia \\
\hline Graz M & 2,698 & 12 & 92 & 267 & 1,629 & 1,186 & 550 & 299 & 1,183 \\
\hline Graz F & 2,519 & 4 & 119 & 208 & 2,031 & 897 & 474 & 211 & 1,157 \\
\hline Total & 5,217 & 16 & 211 & 475 & 3,660 & 2,083 & 1,024 & 510 & 2,340 \\
\hline $\begin{array}{c}\text { Maribor } \\
\text { M }\end{array}$ & 376 & 2 & 98 & 27 & 234 & 387 & 104 & 22 & 184 \\
\hline $\begin{array}{c}\text { Maribor } \\
\text { F }\end{array}$ & 325 & 1 & 35 & 21 & 232 & 356 & 88 & 8 & 156 \\
\hline Total & 701 & 3 & 132 & 48 & 466 & 743 & 192 & 30 & 340 \\
\hline $\begin{array}{c}\text { Towns } \\
\text { Frontier }\end{array}$ & Austria & Austria & Salzburg & Silesia & Tirol and & Hungary & Total & Foreigners \\
\hline Graz M & 70 & 603 & 2,102 & 131 & 283 & 379 & 3,714 & 16,291 & 936 \\
\hline $\begin{array}{c}\text { Graz F } \\
\text { Total }\end{array}$ & 54 & 706 & 2,402 & 143 & 269 & 411 & 2,392 & 14,039 & 969 \\
\hline $\begin{array}{c}\text { Maribor } \\
\text { M }\end{array}$ & 9 & 56 & 236 & 27 & 48 & 74 & 1,024 & 2,833 & 121 \\
\hline $\begin{array}{c}\text { Maribor } \\
\text { F }\end{array}$ & 3 & 54 & 282 & 18 & 50 & 73 & 112 & 1,834 & 80 \\
\hline Total & 12 & 110 & 518 & 45 & 98 & 147 & 1,136 & 4,667 & 201 \\
\hline$\quad$ Sour & 54 & 274 & 562 & 790 & 6,106 & 30,330 & 1,935 \\
\hline
\end{tabular}

Source: Bevölkerung 1882: 50-51.

In the early $20^{\text {th }}$ century, the economic growth of Graz began to slow down. According to the number of employees in industry and commerce, Graz increasingly lagged behind the leading industrial centres such as Vienna, Trieste and Prague, which reflected on its demographic processes. Between 1900 and 1910, of all the towns surveyed, Varaždin (5.7\%), Maribor (13.79\%) and Graz (14.75\%) had the smallest population increase (Table 5).

Between 1869 and 1880, the population of Osijek grew by $5.53 \%$, and in the next census period by modest $8.61 \%$. Rapid growth was recorded in the late $19^{\text {th }}$ and early $20^{\text {th }}$ century as a result of road construction and increased immigration, primarily of the Hungarian population. Regulation of the Drava river from Osijek to Donji Miholjac and Barcs, as part of the so-called Danube Path, and the construction of railroads Osijek - Vrpolje (1870), Osijek - Vinkovci (1879), Osijek - Našice - Batrina (1894), Osijek - Vrpolje (1904) and Osijek - Vinkovci (1910) for the purpose of exploiting timber from Slavonia and Podravina forests (with the involvement of 
Hungarian and domestic major capital), supplying rock salt to south-eastern Europe, exporting livestock and other agricultural products etc., played the key role in the process of industrialization, urbanization and social stratification in Osijek. ${ }^{20}$

Unlike Varaždin, other towns recorded significant population growth in the 1870s (Zagreb 43.21\%, Maribor 36.84\%, Graz 17.6\%, Osijek 8.61\%) as a result of intensified immigration due to favourable socio-economic movements triggered by the development of transport infrastructure and industrialization. These parameters were almost absent in Varaždin, resulting in negative demographic indicators (population decline by $2.87 \%$ and slow growth in upcoming decades). The fastest growth was recorded in Zagreb, which tripled its population in that period. However, the level of urbanization at the time could not provide the basis for the development of the type of civil society present in leading cities of the Monarchy.

\section{The relation between the natural and the migration population movements}

In order to determine the ratio and the importance of migration in overall population movements, it is necessary to consider the relation between the natural and the migration population movements. In the first decade of the $20^{\text {th }}$ century, statistical indicators show population increase in all of the towns considered (Table 8). In Graz, this increase amounted to about $10 \%$, half of which was due to natural increase and the other half to immigration. The increase of population in Varaždin by the modest $5.7 \%$ is solely attributable to immigration, the same as in Osijek $(23.84 \%)$, along with the presence of natural depopulation (-88), and in Zagreb which recorded the highest population increase (29.4\%) of all towns considered.

Total 8: Migration and natural population movements in selected towns of Civil Croatia and Styria (1900-1910)

\begin{tabular}{|c|c|c|c|c|c|c|c|c|c|c|c|c|}
\hline & 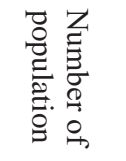 & & 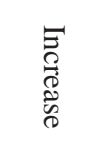 & $0^{\circ}$ & 莺. & 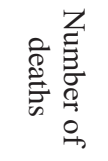 & 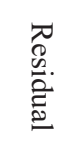 & $0^{\circ}$ & 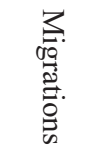 & $d^{0}$ & 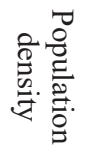 & \\
\hline $\begin{array}{c}\text { Towns/ } \\
\text { Year }\end{array}$ & 1900 & 1910 & & & & & & & & & 1900 & 1910 \\
\hline Graz & 138,080 & 151,781 & 13,701 & 9.92 & 43,228 & 35,237 & 7,991 & 5.79 & 5,710 & 4.13 & 6,276 & 6,899 \\
\hline Maribor & 24,601 & 27,994 & 3,393 & 13.79 & 6,349 & 6,281 & 68 & 0.28 & 3,325 & 13.51 & 3,356 & 3,460 \\
\hline Varaždin & 11,494 & 12,149 & 655 & 5.7 & 336 & 251 & 85 & 0.73 & 570 & 4.43 & 193 & 200 \\
\hline Zagreb & 57,698 & 74,703 & 17,013 & 29.4 & 2,323 & 1,901 & 422 & 0.73 & 16,571 & 28.73 & 912 & 1,182 \\
\hline Osijek & 23,018 & 28,505 & 5,487 & 23.84 & 741 & 850 & -88 & 0.38 & 5,575 & 24.22 & 440 & 500 \\
\hline
\end{tabular}

Source: Bevölkerung 1912: 31, SG II: 10, 116-118.

20 ŽIVAKOVIĆ-KERŽE 2010: 75-78; ŽIVAKOVIĆ-KERŽE 2003: 211-230. 
An analysis of the natural population movement in Varaždin during a ten-year period $(1901-1910)$ revealed a general fertility rate in the first decade of the $20^{\text {th }}$ century of, on average, 27 births per 1,000 inhabitants. As the given data show, the birth rate was gradually decreasing (below 25\% in 1909), as well as the death rate (20.66\% in 1910), which resulted in a higher natural population increase and positive demographic trends, with some variations, most noticeably in death rates in 1905, 1906 and 1909, which led to a negative natural increase that affected overall demographic processes (Table 9).

Table 9: The number of births and deaths in Varaždin and the rate of natural increase (1901-1910)

\begin{tabular}{cccccc}
\hline Year & $\begin{array}{c}\text { Number } \\
\text { of births }\end{array}$ & $\begin{array}{c}\text { Number } \\
\text { of deaths }\end{array}$ & $\begin{array}{c}\text { Average birth rate } \\
(\%)\end{array}$ & $\begin{array}{c}\text { Average death rate } \\
(\%)\end{array}$ & $\begin{array}{c}\text { Natural } \\
\text { increase }\end{array}$ \\
\hline 1901 & 324 & 371 & 28.18 & 32.27 & -47 \\
\hline 1902 & 386 & 305 & 29.62 & 23.41 & 81 \\
\hline 1903 & 368 & 297 & 28.25 & 22.61 & 71 \\
\hline 1904 & 363 & 340 & 27.52 & 25.78 & 23 \\
\hline 1905 & 335 & 384 & 25.43 & 29.15 & -49 \\
\hline 1906 & 355 & 395 & 26.9 & 29.93 & -40 \\
\hline 1907 & 333 & 329 & 25.23 & 24.92 & 4 \\
\hline 1908 & 369 & 341 & 27.84 & 25.73 & 28 \\
\hline 1909 & 332 & 341 & 24.98 & 25.67 & -9 \\
\hline 1910 & 336 & 251 & 27.65 & 20.66 & 85 \\
\hline
\end{tabular}

Source: SG I: 150-152; SG II: 116-118.

Adverse natural movement in Croatian towns at the turn of the century must be correlated with the high death rate of new-borns (Table 10), which amounted to almost a third of total deaths in the five-year period in question (1906 - 1910). Such a high death rate had an impact on the overall population trends in Croatian towns, slowing their growth and causing gradual imbalance in age groups. ${ }^{21}$

Table 10: Child mortality of children under the age of 7 in selected towns of Civil Croatia (1906-1910)

\begin{tabular}{cccccc}
\hline Towns/Year & 1906 & 1907 & 1908 & 1909 & 1910 \\
\hline Varaždin & 135 & 83 & 105 & 94 & 62 \\
\hline Zagreb & 627 & 576 & 667 & 719 & 614 \\
\hline Osijek & 324 & 346 & 274 & 242 & 277 \\
\hline
\end{tabular}

Source: SG II: 167.

21 The most common diseases that caused the death of children at the earliest age were: measles, smallpox, scarlet fever, fever, pertussis, diarrhoea and diphtheria. SG II: 186-187. 
Table 11: The total number of deaths in selected towns of Civil Croatia (1906-1910)

\begin{tabular}{cccccc}
\hline Towns/Year & 1906 & 1907 & 1908 & 1909 & 1910 \\
\hline Varaždin & 395 & 329 & 341 & 341 & 251 \\
\hline Zagreb & 1,863 & 1,873 & 1,932 & 1,976 & 4,263 \\
\hline Osijek & 884 & 946 & 812 & 768 & 850 \\
\hline
\end{tabular}

Source: SG II: 116-118.

An analysis of quantitative data on the age structure of population in Varaždin in 1900 shows a high proportion of younger ( 0 to 15 years old) and middle-aged population groups ( 16 to 40 years old), with a declined share of population over 40 and 60 years of age. The above data evidently show a continuation of the transition process of mortality with a slight decline in child mortality, which can be seen in the age groups of young people who, having survived the first five years of age, entered adolescence (Table 12; Chart 2). This trend was the result of adequate health care (prevention of epidemics, regular vaccination, increased number of doctors and midwives), general education and other.

Table 12: Age structure of the population of Varaždin and Zagreb (1900)

\begin{tabular}{ccccccc}
\hline Town & \multicolumn{3}{c}{ Varaždin } & & \multicolumn{3}{c}{ Zagreb } \\
\hline Age & Men & Women & Total & Men & Women & Total \\
\hline 0 to 4 & 519 & 440 & 959 & 1,915 & 1,885 & 3,800 \\
\hline 5 to 9 & 454 & 493 & 947 & 1,557 & 1,591 & 3,148 \\
\hline 10 to 14 & 544 & 485 & 1,029 & 2,011 & 1,841 & 3,852 \\
\hline 15 to 19 & 548 & 468 & 1,016 & 2,729 & 2,714 & 5,443 \\
\hline 20 to 24 & 1,245 & 389 & 1,634 & 4,130 & 2,342 & 6,472 \\
\hline 25 to 29 & 378 & 317 & 695 & 2,131 & 1,896 & 4,027 \\
\hline 30 to 39 & 612 & 663 & 1,275 & 3,339 & 3,262 & 6,601 \\
\hline 40 to 49 & 514 & 521 & 1,035 & 2,230 & 2,333 & 4,563 \\
\hline 50 to 59 & 383 & 404 & 787 & 1,544 & 1,563 & 3,107 \\
\hline 60 to 69 & 264 & 311 & 575 & 776 & 1,005 & 1,781 \\
\hline 70 to 79 & 123 & 164 & 287 & 326 & 424 & 750 \\
\hline Over 80 & 41 & 29 & 70 & 71 & 104 & 175 \\
\hline Unknown & $/$ & 2 & 2 & 7 & 7 & 14 \\
\hline
\end{tabular}

Source: SG I: 86.

An analysis of the number of births by gender during the ten-year period (1901 - 1910) shows a differential birth rate, meaning that, on average, more male than female children were born, with the exception of 1910 (Table 13). In the age group of 0 to 4 year olds, female to male ratio was 98 to 100 . However, in the overall gender structure of the Varaždin population, shown here for the ten-year period 


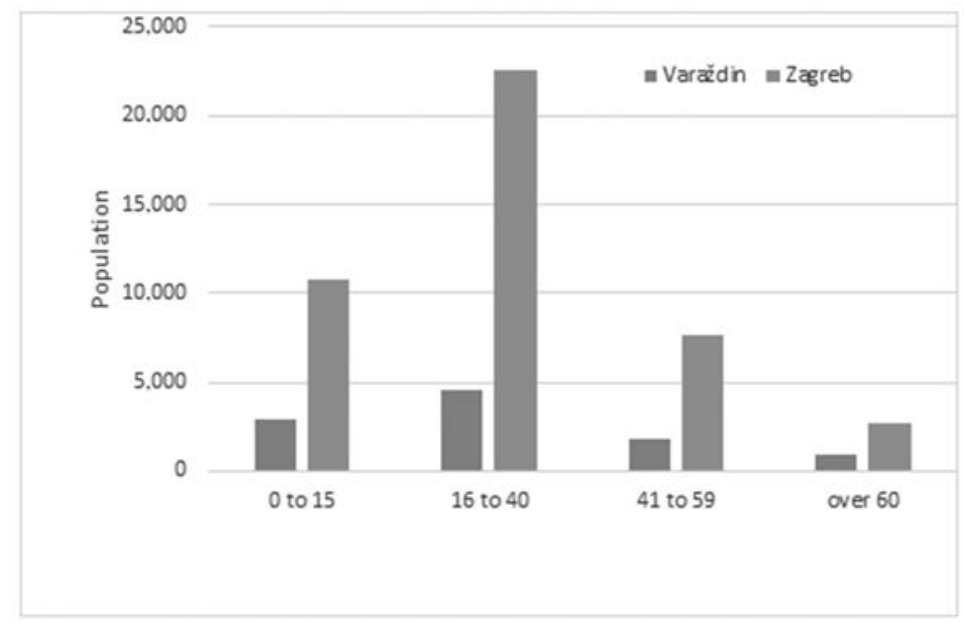

Chart 2: The age structure of the population in Varaždin and Zagreb (1900) (1880 - 1900), there was a slight predominance of female population. ${ }^{22}$ This is due to the inclusion of the male, working-age population (aged 25 to 29) in migration processes that coincided with the beginning of demographic transition.

Table 13: The number of births by gender in Varaždin (1901 - 1910)

\begin{tabular}{cccc}
\hline Year & Male & Female & Total \\
\hline 1901 & 186 & 138 & 324 \\
\hline 1903 & 197 & 171 & 368 \\
\hline 1905 & 169 & 166 & 335 \\
\hline 1907 & 198 & 135 & 333 \\
\hline 1910 & 165 & 171 & 336 \\
\hline
\end{tabular}

Source: SG I: 153; SG II: 156

The adverse natural population movement in Croatian towns at the turn of the century induced, on the one hand, an immigration wave, while on the other it had significant impact on emigrational processes which were considerably slower compared to the overall area of Civil Croatia. ${ }^{23}$ By analysing statistical information on temporarily absent population in Varaždin, Zagreb and Osijek for the 1901 - 1910 period, it is noticeable that emigration waves were primarily directed toward the rest of Croatia and Central Europe (Table 14).

22 According to statistics, the proportion of men in relation to women $(1880-1910)$ for the town of Varaždin was as follows: $1880=100: 104 ; 1890=100: 107 ; 1900=100: 110 ; 1910=100$ : 102. SG II: 12.

23 Between 1905 and 1910, 68,774 people emigrated from Croatia and Slavonia, the majority to overseas countries $-54,930$ of them. SG I: 242-243. 
Table 14: Population temporary absent from the selected towns of Civil Croatia (1900) regarding the countries they inhabited

\begin{tabular}{cccccccccccr}
\hline Towns & $\begin{array}{c}\text { Cro. } \\
\text { and } \\
\text { Slav. }\end{array}$ & Rijeka & Hungary & $\begin{array}{c}\text { Bos. } \\
\text { and } \\
\text { Herz. }\end{array}$ & Austria & Germany & $\begin{array}{c}\text { Other } \\
\text { countries }\end{array}$ & America & Unknown Total \\
\hline Varaždin & 211 & 5 & 39 & 5 & 50 & 10 & 3 & 15 & 18 & 360 \\
\hline Zagreb & 552 & 20 & 61 & 26 & 177 & 27 & 37 & 44 & 2 & 962 \\
\hline Osijek & 266 & 2 & 99 & 31 & 64 & 11 & 7 & 18 & 12 & 510 \\
\hline
\end{tabular}

Source: SG II: 133.

Table 15: Emigration from selected towns of Civil Croatia (1901-1910)

\begin{tabular}{|c|c|c|c|c|c|c|c|c|c|c|c|c|}
\hline 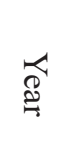 & 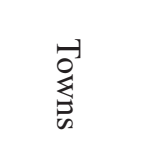 & 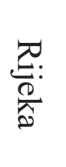 & 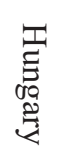 & $\begin{array}{l}\text { 忍 } \\
\text { 品. } \\
\text { :. }\end{array}$ & 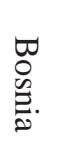 & $\begin{array}{l}\mathscr{\Omega} \\
\stackrel{0}{2} \\
\stackrel{0}{2} .\end{array}$ & 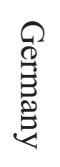 & 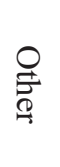 & 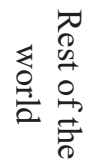 & $\stackrel{\overrightarrow{0}}{\stackrel{0}{D}}$ & $\frac{3}{9}$ & $\begin{array}{l}\bigotimes_{0} \\
\stackrel{\Xi}{\Theta}\end{array}$ \\
\hline \multirow[t]{3}{*}{1901} & Varaždin & 1 & 1 & 7 & 3 & 1 & I & 5 & 5 & 22 & 14 & 8 \\
\hline & Zagreb & 12 & 28 & 79 & 16 & 6 & 7 & 5 & 3 & 156 & 101 & 55 \\
\hline & Osijek & 3 & 332 & 44 & 47 & 11 & I & 14 & I & 451 & 223 & 228 \\
\hline \multirow[t]{3}{*}{1904} & Varaždin & 1 & 65 & 53 & 1 & 1 & 1 & 8 & 1 & 130 & 81 & 49 \\
\hline & Zagreb & 9 & 20 & 67 & 20 & 3 & 1 & 12 & 5 & 137 & 92 & 45 \\
\hline & Osijek & 2 & 116 & 23 & 23 & 6 & 8 & 1 & 3 & 181 & 92 & 89 \\
\hline \multirow[t]{3}{*}{1906} & Varaždin & 1 & 20 & 59 & 1 & 8 & 1 & 1 & I & 88 & 48 & 40 \\
\hline & Zagreb & 34 & 33 & 105 & 42 & 2 & 6 & 7 & 1 & 232 & 147 & 85 \\
\hline & Osijek & 1 & 9 & I & I & 1 & I & I & / & 9 & 6 & 3 \\
\hline \multirow[t]{3}{*}{1910} & Varaždin & 1 & 6 & 15 & 1 & 1 & 1 & 3 & 1 & 24 & 12 & 12 \\
\hline & Zagreb & 8 & 14 & 36 & 7 & 1 & 1 & 1 & 1 & 44 & 23 & 21 \\
\hline & Osijek & / & I & I & I & l & / & 1 & / & l & I & / \\
\hline
\end{tabular}

Source: SG I: 25; SG II: 49.

Quite the opposite processes took place in counties. By comparing statistical data on emigration from Varaždin County and the town of Varaždin (1901 - 1910), it is clear that emigrational processes in the County were much stronger and had a different direction as a result of the agrarian crisis and the over-population associated with it, occurring due to the fragmentation of cooperatives, uneven industrialization, underdeveloped markets and slow urbanization. We can conclude that Varaždin could not absorb the meagre part of the rural population of north-western Croatia which emigrated mainly to North America. The biggest emigration wave was recorded between 1905 and 1907, when 3,454 people went to North America. In 1908, the number of emigrants dropped sharply, but the trend was overturned in the following two decades with an additional 1,200 emigrants. The second, in terms of intensity, was the emigration wave directed towards Germany. Between 
1905 and 1908, 718 people from Varaždin County moved to Germany. In 1909, the number dropped drastically (only 26 people). Such large fluctuations in the number of emigrants were the result of economic developments and the need for labour in the American and the German area (Table 16).

Table 16: The number of emigrants and the directions of emigration from Varaždin County (1901-1910)

\begin{tabular}{cccccccccc}
\hline Year & $\begin{array}{c}\text { Number } \\
\text { of } \\
\text { emigrants }\end{array}$ & Rijeka Hungary & Austria & Bosnia Germany & $\begin{array}{c}\text { Other } \\
\text { European } \\
\text { countries }\end{array}$ & $\begin{array}{c}\text { North } \\
\text { America }\end{array}$ & Others \\
\hline 1901 & 144 & $/$ & 18 & 29 & 3 & 6 & 9 & 78 & 1 \\
\hline 1902 & 150 & $/$ & & 24 & 1 & 7 & 3 & 115 & $/$ \\
\hline 1903 & 221 & $/$ & 1 & 6 & 2 & 8 & 2 & 199 & 3 \\
\hline 1904 & 51 & $/$ & 10 & 5 & 1 & 2 & 7 & 18 & 8 \\
\hline 1905 & 1,198 & 5 & 7 & 298 & 2 & 120 & 17 & 743 & 6 \\
\hline 1906 & 1,328 & $/$ & $/$ & 97 & 2 & 156 & 18 & 1,053 & 2 \\
\hline 1907 & 2,002 & $/$ & $/$ & 70 & 1 & 245 & 28 & 1,658 & $/$ \\
\hline 1908 & 439 & 1 & $/$ & 86 & 2 & 197 & 53 & 100 & $/$ \\
\hline 1909 & 611 & $/$ & $/$ & 94 & $/$ & 26 & 5 & 486 & $/$ \\
\hline 1910 & 722 & $/$ & 1 & 157 & $/$ & 22 & 5 & 535 & 2 \\
\hline
\end{tabular}

Source: SG I: 244; SG II: 200.

\section{Ethnic composition of the population}

Information on the population's land of origin was first included in the 1880s census. Although this information cannot be directly linked with migrations, it is, along with information on religion and language, quite significant for the attempt to reconstruct the mobility level of the population of an area. According to the 1880 data, the majority of population was born in the same place in which they were registered. In Varaždin, 59.89\% of the population was born in the town, and a further $17.54 \%$ in the wider homeland, Croatia and Slavonia, amounting to a total of $76.82 \%$. The remaining $23.82 \%$ were born on the territory of Austria-Hungary. Comparing the results of the 1880 and 1910 censuses, there is an increase in local population by $10 \%$, as well as a decline in the number of people born in Austria (by over $4 \%$ ) and a slight increase in the number of people born in Hungary (2.37\%), which indicates a low population mobility (Tables 17 and 18). A higher level of population mobility was present in Zagreb and Osijek, which was primarily related to Croatia and Slavonia. In 1910, 38.31\% of the population of Zagreb at the time was born in Zagreb, while a further $38.4 \%$ were born in Croatia and Slavonia, totalling $76.61 \%$ (Table 18). Also, there is a noticeable significant decline in the number of births in Austrian lands. This can be explained by increased industrialization of Austrian districts and a huge demand for labour. 
Table 17: Present population according to their place of birth in selected towns of Civil Croatia (1880 and 1910)

\begin{tabular}{ccccccccc}
\hline $\begin{array}{c}\text { Year: } \\
1880\end{array}$ & $\begin{array}{c}\text { Croatia } \\
\text { and } \\
\text { Slavonia }\end{array}$ & Town & Rijeka & Hungary & Austria & Bosnia & Others & Unknown \\
Towns & & & & & & & \\
\hline Varaždin & 7,968 & 6,149 & 11 & 953 & 1,368 & 4 & 60 & 7 \\
\hline Zagreb & 20,014 & 13,143 & 130 & 1,516 & 7,004 & 56 & 486 & 12 \\
\hline Osijek & 12,749 & 10,625 & 15 & 4,199 & 1,031 & 8 & 186 & 5 \\
\hline $\begin{array}{c}\text { Year: } \\
1910\end{array}$ & $\begin{array}{c}\text { Croatia } \\
\text { and }\end{array}$ & Town & Rijeka & Hungary & Austria & Bosnia & Others & Unknown \\
\hline Towns & Slavonia & & & & & & & \\
\hline Varaždin & 10,607 & 9,175 & 13 & 1,548 & 1,135 & 23 & 69 & 3 \\
\hline Zagreb & 60,553 & 30,282 & 300 & 6,444 & 10,036 & 823 & 872 & 10 \\
\hline Osijek & 21,882 & 15,137 & 24 & 7,616 & 1285 & 243 & 326 & 10 \\
\hline
\end{tabular}

Source: SG I: 68; SG II: 47.

Table 18: Present population according to their place of birth in selected towns of Civil Croatia (1880 and 1910) in percentage

\begin{tabular}{ccccccccc}
\hline $\begin{array}{c}\text { Year: } \\
1880-\end{array}$ & $\begin{array}{c}\text { Croatia } \\
\text { and } \\
\text { Towns }\end{array}$ & Town & Rijeka & Hungary & Austria & Bosnia & Others & Unknown \\
\cline { 1 - 6 } Varaždin & 76.82 & 59.28 & 0.1 & 9.18 & 13.19 & 0.03 & 0.57 & 0.06 \\
\hline Zagreb & 68.49 & 44.98 & 0.44 & 5.18 & 23.97 & 0.6 & 1.66 & 0.04 \\
\hline Osijek & 70.04 & 53.72 & 0.08 & 23.07 & 5.66 & 0.04 & 1.02 & 0.02 \\
\hline Year: 1910 & $\begin{array}{c}\text { Croatia } \\
\text { and }\end{array}$ & Town & Rijeka & Hungary & Austria & Bosnia & Others & Unknown \\
\hline Towns & Slavonia & & & & & & & \\
\hline Varaždin & 79.16 & 68.48 & 0.09 & 11.55 & 8.47 & 0.17 & 0.51 & 0.02 \\
\hline Zagreb & 76.61 & 38.31 & 0.37 & 8.15 & 12.69 & 1.04 & 1.1 & 0.01 \\
\hline Osijek & 69.71 & 48.22 & 0.07 & 24.26 & 4.09 & 0.77 & 1.03 & 0.03 \\
\hline
\end{tabular}

Source: SG I: 68; SG II: 47.

According to statistical data for the year 1900, the percentage of foreign population in Graz amounted to $0.94 \%$. A decade later, this percentage decreased to $0.91 \%$. The largest group of foreigners $(80 \%$ or 10,652 people in 1900 , and $78 \%$ or 10,053 people in 1910) consisted of inhabitants of Hungarian lands, among which 674 persons indicated Croatia and Slavonia as their land of origin in the year 1900, while in 1910 that number almost doubled (1,710 people or $1.7 \%)$ as a result of stronger emigration processes in the Croatian region. Along with Germans (1,496 people), a smaller proportion belonged to Italians, Swiss, the 
population of the Balkan Peninsula and others, whose share was declining. In the early $20^{\text {th }}$ century $79 \%$ of the foreign population in Maribor originated from countries of the Hungarian crown, half of which were of Croatian-Slavonian origin, but their share declined in $1910 .{ }^{24}$ A complete picture of migration movements and the share of foreigners in the population of Croatian towns in the $1880 \mathrm{~s}$ were determined based on information on their native language. Zagreb (13.45\%), Sisak (12.82\%) and Varaždin (6.95\%) had the highest number of inhabitants whose native language was Slovenian. Geographical proximity, railway and road communications, together with employment in trade and industry were the main factors that attracted Slovenian population to these towns. However, their share halved in 1910 (Tables 19 and 20).

In 1880 , about $50 \%$ of residents in Osijek indicated German as their native language, surpassing the number of those whose native language was Croatian or Serbian by nearly $10 \%$. This was the result of German colonization waves that swept Slavonia and Syrmia during the $18^{\text {th }}$ and $19^{\text {th }}$ centuries, encouraged by the Austrian government for economic, religious and national interests. In the early $20^{\text {th }}$ century, German immigration gradually subsided, resulting in the reduction of their share in the total population of Croatian towns. In Varaždin and Zagreb, their share was halved in 1910 compared to 1880, while in Osijek it was reduced by a quarter. It is interesting that the German immigration wave, which swept the Slovenian and Austrian territory at the end of the $19^{\text {th }}$ century, was much lower in intensity compared to the Slavonian area.

Unlike Graz, which was one of the more desirable destinations of Czech emigrants during the second half of the $19^{\text {th }}$ century, in the Croatian area it most intensely affected Zagreb, with a tendency of growth. Compared to 1880, Czech population in Zagreb doubled in 1910. Czech community in Osijek in the same period increased by only 133 people as the result of slow immigration, inclusion in emigration flows and assimilation. In Varaždin, it did not even reach 1\% of total population throughout the entire studied period (Table 20).

Table 19: Present population according to their native language in selected towns of Civil Croatia (1880 and 1910)

\begin{tabular}{|c|c|c|c|c|c|c|c|}
\hline $\begin{array}{l}\text { Year: } \\
1880\end{array}$ & \multirow{2}{*}{$\begin{array}{l}\text { Croatian } \\
\text { or } \\
\text { Serbian }\end{array}$} & \multirow[t]{2}{*}{ Slovenian } & \multirow{2}{*}{ Czech } & \multirow{2}{*}{ Hungarian } & \multirow{2}{*}{ German } & \multirow[t]{2}{*}{ Italian } & \multirow[t]{2}{*}{ Other } \\
\hline Towns & & & & & & & \\
\hline Varaždin & 8,548 & 721 & 93 & 244 & 703 & 45 & 17 \\
\hline Zagreb & 20,895 & 3,931 & 610 & 584 & 2,687 & 385 & 126 \\
\hline Osijek & 7,482 & 25 & 329 & 1,152 & 8,970 & 78 & 65 \\
\hline
\end{tabular}

$\overline{24}$ Berufsstatistik 1904: 2; Bevölkerung 1912: 4. 


\begin{tabular}{|c|c|c|c|c|c|c|c|}
\hline $\begin{array}{l}\text { Year: } \\
1910\end{array}$ & $\begin{array}{c}\text { Croatian } \\
\text { or }\end{array}$ & Slovenian & Czech & Hungarian & German & Italian & Others \\
\hline Towns & Serbian & & & & & & \\
\hline Varaždin & 10,645 & 432 & 113 & 431 & 479 & 23 & 26 \\
\hline Zagreb & 59,824 & 5,119 & 1,160 & 3,871 & 3,965 & 324 & 440 \\
\hline Osijek & 13,427 & 148 & 462 & 3,536 & 10,778 & 36 & 118 \\
\hline
\end{tabular}

Source: SG I: 68; SG II: 47.

Table 20: Present population according to their native language in selected towns of Civil Croatia (1880 and 1910) in percentage

\begin{tabular}{|c|c|c|c|c|c|c|c|}
\hline Year: 1880 & & Slonnizn & Czech & Hunoarian & German & Italian & Other \\
\hline Towns & Serbian & Siovenildal & Czech & Hungarlan & German & Itanlan & Dth \\
\hline Varaždin & 82.42 & 6.95 & 0.9 & 2.35 & 6.78 & 0.43 & 0.17 \\
\hline Zagreb & 75.51 & 13.45 & 2.19 & 2 & 9.2 & 1.32 & 0.43 \\
\hline Osijek & 41.11 & 0.68 & 1.81 & 6.33 & 49.28 & 0.43 & 0.36 \\
\hline Year: 1910 & $\begin{array}{c}\text { Croatian } \\
\text { or } \\
\text { Serbian }\end{array}$ & Slovenian & Czech & Hungarian & German & Italian & Other \\
\hline Varaždin & 87.62 & 3.55 & 0.76 & 3.54 & 3.94 & 0.18 & 0.21 \\
\hline Zagreb & 80.08 & 6.85 & 1.55 & 5.18 & 5.3 & 0.43 & 0.57 \\
\hline Osijek & 47.1 & 0.51 & 1.62 & 12.4 & 37.81 & 0.12 & 0.39 \\
\hline
\end{tabular}

Source: Calculation according to available data: SG I: 68; SG II: 47.

In 1880 a significant number of Hungarian-born inhabitants was recorded in Osijek $(4,199$ or $23.7 \%$ ). Their number increased to 7,616 or $24.26 \%$ in 1910 (Tables 17 and 18) due to the colonization of the Hungarian border area as part of the strategy by Hungarian ruling circles after the Croatian-Hungarian Settlement, but also because of heavy emigration in the early $20^{\text {th }}$ century following unfavourable socio-economic relations in the country, which even the Hungarian government failed to stop by a variety of administrative measures. Subject to emigration were mostly impoverished servants and labourers from large landholding estates, about two million of them excluding family members in the early $20^{\text {th }}$ century. ${ }^{25}$ The majority of that emigration wave was directed towards the Austrian part of the Monarchy. In 1880, 6,106 inhabitants of Graz had been born in Hungary, 40\% of which were women. Their number increased to 9,946 in 1900 of the total of 10,652 inhabitants born in the countries of the Hungarian crown. In 1910, the number of immigrants slightly decreased. Of course, most of the Hungarian immigrants resided in Vienna, where over 133,000 of them lived in 1900, with 129,000 of

25 HANÁK 1995: 158-186. 
them having been born in Hungary. ${ }^{26}$ Part of this emigration wave stopped in Slavonia, Zagreb County, Croatian Littoral and Rijeka. ${ }^{27}$ In this context, the increase of Hungarian-speaking citizens in Zagreb was significant: from 584 in 1880 to 3,871 in 1910, equalling the number of speakers of German (Table 19).

In 1880, in Varaždin there were 244 inhabitants $(2.35 \%)$ whose native language was Hungarian (Tables 19 and 20). During a thirty-year period, their share increased by $3.54 \%$ or 431 people, indicating that the Hungarian emigration wave bypassed the Varaždin area due to low level of urbanization, lack of free land estates and slow industrialization. Most of these emigrants were officials working in administration, financial institutions and railways in the context of political efforts by Hungarian authorities to put pressure on Croatia and further reduce its autonomy. An analysis of working population by occupation and native language shows that the vast majority of immigrants were employed in non-agricultural activities: a variety of crafts, trade, transport and the army, in particular Hungarian, Czech and German settlers in Zagreb and Osijek. Certain deviations can be found in Osijek, where a significant number of German and Hungarian immigrants worked in agriculture or as labourers and servants at major Slavonian land estates. ${ }^{28}$

Regarding religious groups in the $1880 \mathrm{~s}$, Roman Catholics are evidently predominant: Maribor (98.06\%), Graz (96.21\%), Varaždin (93.3\%), Zagreb (91.22\%) and Osijek ( $81.15 \%)$. Due to migration movements in the central European region in the first decade of the $20^{\text {th }}$ century, the proportion of Catholics started to decline (Maribor: 95.1\%, Graz: 92.84\%, Zagreb: 88\%, Osijek: 81.25\%) while the number of Jews increased (except in Varaždin where their share was decreasing), as well as the number of Protestants and Orthodox population (Tables 21 and 22).

Table 21: Religious groups in selected towns of Civil Croatia and Styria (1880)

\begin{tabular}{|c|c|c|c|c|c|c|}
\hline \multirow{2}{*}{$\begin{array}{c}\text { Year: } 1880 \\
\text { Towns } \\
\text { In number }\end{array}$} & \multirow[b]{2}{*}{$\begin{array}{l}\text { Roman } \\
\text { Catholics }\end{array}$} & \multirow[b]{2}{*}{$\begin{array}{c}\text { Greek } \\
\text { Catholics }\end{array}$} & \multirow[b]{2}{*}{ Orthodox } & \multirow[b]{2}{*}{ Protestants } & \multirow[b]{2}{*}{ Jews } & \multirow[b]{2}{*}{ Other } \\
\hline & & & & & & \\
\hline Varaždin & 9,675 & 8 & 82 & 26 & 578 & 2 \\
\hline Zagreb & 26,653 & 76 & 959 & 233 & 1,286 & 11 \\
\hline Osijek & 14,769 & 7 & 1,655 & 273 & 1,493 & 4 \\
\hline Graz & 94,088 & 22 & 137 & 2,192 & 1,211 & 32 \\
\hline Maribor & 17,287 & 6 & 17 & 274 & 37 & 11 \\
\hline
\end{tabular}

\footnotetext{
$26 \quad$ Berufsstatistik 1904: 2; Bevölkerung 1912: 4.

27 MAKKAI 2011: 66-76; VRANJEŠ-ŠOLJAN 2003: 258.

28 SG I: 138; SG II: 108.
} 


\begin{tabular}{ccccccc}
\hline Year: 1880 & \multirow{2}{*}{$\begin{array}{c}\text { Roman } \\
\text { Catholics }\end{array}$} & $\begin{array}{c}\text { Greek } \\
\text { Catholics }\end{array}$ & Orthodox & Protestants & Jews & Other \\
\hline Varaždin & 93.3 & 0.07 & 0.79 & 0.25 & 5.57 & 0.02 \\
\hline Zagreb & 91.22 & 0.26 & 3.28 & 0.8 & 4.4 & 0.04 \\
\hline Osijek & 81.15 & 0.04 & 9.09 & 1.5 & 8.2 & 0.02 \\
\hline Graz & 96.21 & 0.02 & 0.14 & 2.24 & 1.23 & 0.03 \\
\hline Maribor & 98.06 & 0.03 & 0.09 & 1.55 & 0.2 & 0 \\
\hline
\end{tabular}

Source: SG I: 24-25; Volkszählung 1882: 36-37.

Table 22: Religious groups in selected towns of Civil Croatia and Styria (1910)

\begin{tabular}{ccccccc}
$\begin{array}{c}\text { Year: } 1910 \\
\begin{array}{c}\text { Towns } \\
\text { In number }\end{array}\end{array}$ & $\begin{array}{c}\text { Roman } \\
\text { Catholics }\end{array}$ & $\begin{array}{c}\text { Greek } \\
\text { Catholics }\end{array}$ & Orthodox & Protestants & Jews & Others \\
\hline Varaždin & 11,342 & 26 & 108 & 69 & 604 & $/$ \\
\hline Zagreb & 65,740 & 306 & 3,363 & 1,038 & 4,192 & 64 \\
\hline Osijek & 22,918 & 107 & 2,258 & 895 & 2,299 & 28 \\
\hline Graz & 140,924 & 152 & 801 & 6,811 & 1,971 & 722 \\
\hline Maribor & 26,623 & 35 & 20 & 1,220 & 66 & 50 \\
\hline Year: 1910 & Roman & Greek & Orthodox & Protestants & Jews & Others \\
\hline Towns \% & Catholics & Catholics & & & & \\
\hline Varaždin & 93.37 & 0.21 & 0.9 & 0.54 & 4.98 & $/$ \\
\cline { 1 - 4 } Zagreb & 88 & 0.41 & 4.51 & 1.39 & 5.61 & 0.08 \\
\hline Osijek & 80.39 & 0.37 & 7.92 & 3.13 & 8.06 & 0.09 \\
\hline Graz & 92.84 & 0.1 & 0.52 & 4.48 & 1.29 & 0.47 \\
\hline Maribor & 95.1 & 0.15 & 0.07 & 4.35 & 0.23 & 0.17 \\
\hline
\end{tabular}

Source: SG II: 25-26; Volkszählung 1912: 44-45.

Statistics show that 82 Orthodox believers lived in Varaždin in 1880, which in all probability roughly corresponded to the number of Serbian community, politically and religiously affiliated with the Varaždin Serbian Orthodox Church District. According to preserved ecclesiastical archives, this community had 85 members in $1884,{ }^{29}$ which approximately corresponds to official statistics. During the thirty-year period, its demographic weakening is visible. In 1910, 108 Orthodox believers were listed, accounting for only $0.9 \%$ of the total population. This situation must be considered in the context of low birth rates and involvement in immigration flows. In the three-year period (1901 - 1903) only 11 members of Orthodox religion were recorded to have been born in Varaždin. In the same period, 155 Orthodox believers were listed as born in Zagreb and 96 in Osijek. ${ }^{30}$ The

29 DAMJANOVIĆ 2013: 319.

30 SG I: 192. 
analysis of birth and death rates $(1880$ - 1900) with regard to religious affiliation on the entire Croatian and Slavonian territory shows significantly higher birth as well as death rates of Orthodox believers compared to the Catholics; moreover, the death rate of the Orthodox exceeded all other religions, resulting in lower natural increase. During the twenty-year period mentioned, the birth rate (births per 1,000 inhabitants) of the Orthodox ranged from $51.1 \%$ to $42.7 \%$, while the death rate (deaths per 1,000 inhabitants) from $45.2 \%$ to $30.4 \%$. For Catholics, the birth rate varied from $45.9 \%$ o to $38.6 \%$, and the death rate from $37.1 \%$ to $26.1 \%$. The Jews had the lowest death rate: from $22.6 \%$ to $12.6 \%{ }^{31}$ Some authors attribute higher death rates among Orthodox population to the living conditions that caused higher mortality of female population between 10 and 60 years of age. ${ }^{32}$ The increase in Orthodox population in Zagreb (from 3.28\% in 1880 to $4.51 \%$ in 1910) resulted from increased immigration of Serbian population, encouraged for political reasons, especially during Khuen-Héderváry's rule (1883 - 1903), to preserve the dualism and the Hungarian hegemony within countries of the Hungarian crown, with the objective of imposing further restrictions and control over Croatian autonomy, relying on the Serbian political and economic elite in Croatia.

The analysis of quantitative information (Table 23) on the movement of the number of entrepreneurs according to their main occupations with regard to religious affiliation in the town of Varaždin in the early $20^{\text {th }}$ century shows that agriculture was practiced exclusively by Catholics. The largest share of workers among the Orthodox can be found in the military and in public services and free professions, this being officials who immigrated to the Varaždin area and who, in the first half of the 1880s, held the highest political and administrative positions. Although few in number, they managed to establish strong religious and political connections. Thanks to political and financial efforts of Ognjeslav Utješenović Ostrožinski, the great prefect of Varaždin County (1875 - 1886), and Milan Vrabčević, the Varaždin commissioner (1881 - 1885), the Serbian Orthodox Church District was founded (1882) and the Orthodox church of Saint George built and furnished in Varaždin (1884).$^{33}$ The largest number of Protestants were employed in the army, mostly junior officers who moved to Varaždin with their families from the Austrian and Hungarian territory.

Economic structure of entrepreneurs among members of the Jewish community shows the traditional orientation towards trade and financial institutions, crafts and public services and free professions (lawyers, doctors, civil servants, etc.). Legal emancipation of Jews as the result of liberal legislation in the 1860s: revocation of various provisions which limited religious, family and economic

\footnotetext{
$31 \quad$ SG I: 240.

32 ARTUKOVIĆ 2001: 50.

33 DAMJANOVIĆ 2013: 317-340.
} 
life (regional approval of marriage, exclusion from certain trades, provisions on wine tax, but not abolition of cemetery lease ${ }^{34}$ ), the construction of new religious and social facilities (a new synagogue in Varaždin built at the South barrow in 1861, the rabbi's residence, a Jewish bath and a school in 1867) ${ }^{35}$ and the need of town authorities for Jewish capital allowed their vertical and horizontal mobility within the social structures which reflected on migration processes. However, they were much more moderate compared to other Croatian towns (for example Osijek, Karlovac, Koprivnica, Križevci and others), which is an indicator of slow economic development of the Varaždin area. Thus, between 1857 and 1870 the number of Jews in Varaždin increased by $30.86 \%$. In Osijek, which had the fastest economic growth, that increase in the same period amounted to as much as $74.66 \% .{ }^{36}$ Between 1880 and 1900, Jewish community in Varaždin had 720 members, which was also its peak, after which a gradual decline is noticeable (Chart 3).

Table 23: The number of entrepreneurs in Varaždin (1900) according to their religion

\begin{tabular}{cccccc}
\hline Entrepreneurs & $\begin{array}{c}\text { Roman } \\
\text { Catholics/ } \\
\text { Greek } \\
\text { Catholics }\end{array}$ & Orthodox & Protestants & Jews & Other \\
\hline $\begin{array}{c}\text { Agricultural } \\
\text { production }\end{array}$ & 1,178 & $/$ & 1 & 7 & $/$ \\
\hline Mining & 1 & $/$ & 1 & $/$ & $/$ \\
\hline Crafts & 1,663 & 9 & 6 & 80 & 2 \\
\hline $\begin{array}{c}\text { Trade and savings- } \\
\text { bank sector }\end{array}$ & 228 & 7 & $/$ & 152 & $/$ \\
\hline Transport & 167 & 3 & $/$ & 10 & $/$ \\
\hline $\begin{array}{c}\text { Public service and } \\
\text { free occupations }\end{array}$ & 478 & 25 & 3 & 23 & $/$ \\
\hline Soldiers & 1,238 & 134 & 54 & 10 & $/$ \\
\hline Workers & 125 & $/$ & $/$ & $/$ & $/$ \\
\hline Household servants & 670 & 4 & 5 & 8 & $/$ \\
\hline Extras/ Pensioners & 301 & 7 & 1 & 19 & $/$ \\
\hline Others & 165 & $/$ & 2 & 1 & $/$ \\
\hline
\end{tabular}

Source: SG I: 139.

34 DAVŽ, 16, GPV, Zapisnici sjednica poglavarstva, zastupstva i pojedinih odbora $1852-1918$, 18. 10. 1872., §. 1372, §. 1373.

35 GROSS 1985: 361-362; DAVŽ, 16, GPV, Zapisnici sjednica poglavarstva, zastupstva i pojedinih odbora 1852 - 1918, 9. 8. 1861., §. 576.; 11. 6. 1867., §. 786.

36 GROSS AND SZABO 1992: 420-421. 


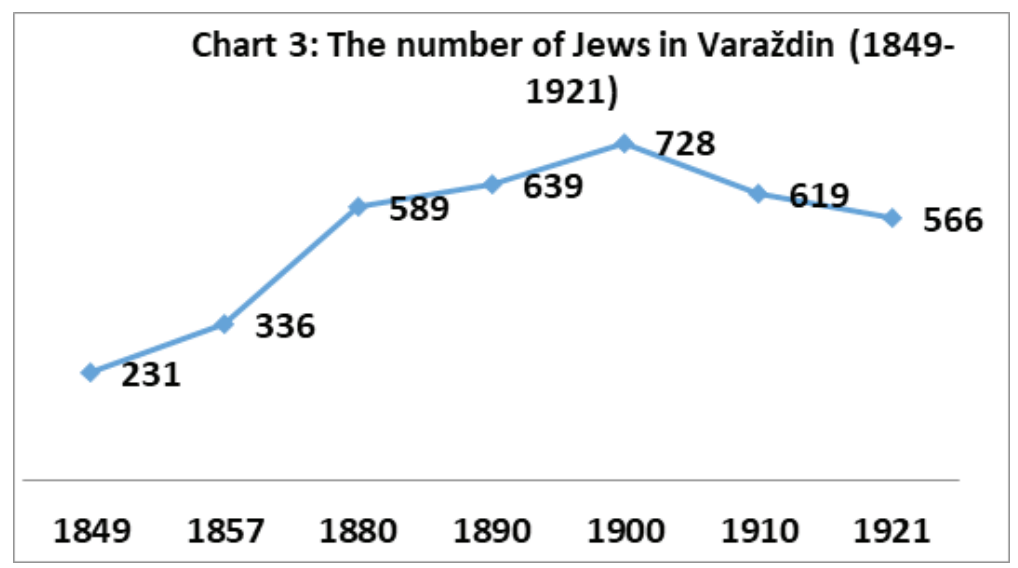

Source: Narodnosni i vjerski sastav stanovništva Hrvatske, 1998 (vol. 3): 3089.

Taken as a whole, migration movements within the Monarchy in the second half of the $19^{\text {th }}$ and the early $20^{\text {th }}$ century were marked by strong waves of emigration of the Hungarian population, including female population, a decline of German colonization and an intensification of external migrations related to overseas countries. Their intensity depended on the socio-economic development of the area of immigration. These movements led to changes in ethnic and religious composition of the population, with a tendency of weakening the dominant Catholic and strengthening the Jewish, Protestant and Orthodox element.

\section{Conclusion}

The first stage of modernization $(1850$ - 1918) in the Central Europe proved to be of key importance in further development of the process of urbanization, industrialization and social stratification of the town of Varaždin, influencing migration trends that were weaker in intensity compared to the Croatian towns and capitals of Central Europe, causing demographic stagnation noticeable in modern structures. The cause of this should be sought in impossibility to construct railway infrastructure, insufficient capital accumulation and late industrialization, considering that the research shows a reversibility pattern in socio-economic development and migration. The proof of reversibility of the socio-economic development (1857 - 1869) characterized by the beginning of industrialization, the ascent of urbanization, immigration (the share of non-natives in the population structure was $26.33 \%$ ) and the growth of total population by $18.32 \%$, followed by a period of economic stagnation (1869 - 1880) which had a negative reflection on demographic movements (reducing the population number by $2.87 \%$ ). In the following decades, demographic movements were positive but extremely slow, which had a low level of population mobility reconstructed upon information 
on the land of origin and language: a large portion of the population was born in Varaždin and spoke Croatian as the mother tongue, with further tendencies of growth in the structure of the total population. The relations between the natural and the migration movement of population in Varaždin during the first decade of the $20^{\text {th }}$ century indicate that population increased as the result of immigration which, given its low intensity, could not ensure significant demographic growth (between 1900 and 1910 the population of Varaždin increased by the modest $5.7 \%)$. Population analysis by age and gender shows a decline of male population between the ages of 25 and 29 (working population), which was the subject of emigration movement directed mainly towards the rest of the national and central European area. A comparison of statistic information on emigration from Varaždin County and the town of Varaždin shows emigrational processes in the County to be of higher intensity and divergent in direction as the result of an agricultural crisis and overpopulation that comes with it, and was the product of the division of agricultural cooperatives. Naturally, the town of Varaždin and the rest of the Croatian area could not have absorbed the meagre part of the rural population of north-western Croatia which emigrated mainly to North America.

\section{Bibliography}

\section{Abbreviations}

GPV: Gradsko poglavarstvo Varaždin [Town Council of Varaždin].

HR-DAVŽ: Hrvatska - Državni arhiv u Varaždinu [Croatia-State Archives in Varaždin].

HR-DAZG: Hrvatska - Državni arhiv u Zagrebu [Croatia-State Archives in Zagreb].

SG: Statistički godišnjak kraljevina Hrvatske i Slavonije. [The Statistical Yearbook of the Kingdom of Croatia and Slavonia.].

\section{Archival materials}

HR-DAVŽ, 16, GPV, Zapisnici sjednica poglavarstva, zastupstva i pojedinih odbora 1852

- 1918 [Records of town government sessions, agencies and individual committees $1852-1918]$.

HR-DAZG, 252, Trgovinska komora u Zagrebu, Sudbeni stol Varaždin, 157, Družtvene tvrtke [Chamber of Commerce in Zagreb, Judicial Court of Varaždin, 157, Public companies].

HR-DAZG, 252, Trgovinska komora u Zagrebu, Sudbeni stol Varaždin, 282, Inokosne tvrtke [Chamber of Commerce in Zagreb, Judicial Court of Varaždin, 282, Private companies]. 


\section{Published sources}

Berufsstatistik nach Ergebnissen der Volkszählung vom 31. December 1890 in den im Reichsrathe vertretenen Königreichen und Ländern H.1. Analytische Bearbeitung und Reichsübersicht. CLXXIII, 178 S. H.2. Niederösterreich. IV, 213 S. H.3. Oberösterrei. 1894. Wien: Kaiserlich-königliche Hof-und Staatsdruckerei.

Die Bevölkerung und Viehstand der im Reichsrathe Vertretenen Königreiche und Länder dann der Militärgränze. Nach der Zählung vom 31. December 1869. 1871. Wien: Kaiserlich-königliche Hof-und Staatsdruckerei.

Die Ergebnisse der Volkszählung und der mit derselben verbundenen Zählung der Häuslichen nutzthiere vom 31 December 1880 in den im reichsrathe Vertretenen Königreichen und Ländern.1882. Wien: Kaiserlich-königliche Hof-und Staatsdruckerei.

Die Ergebnisse der Volkszählung vom 31. Dezember 1900 in den Reicchsrate vertretenen Königreichen und Ländern. 1905. Wien: Kaiserlich-königliche Hof-und Staatsdruckerei.

Die Ergebnisse der Volkszählung vom 31. Dezember 1910 in den Reicchsrate vertretenen Königreichen und Ländern. 1912. Wien: Kaiserlich-königliche Hof-und Staatsdruckerei.

Narodnosni $i$ vjerski sastav stanovništva Hrvatske: 1880.-1991. po naseljima [Ethnic and religious composition of the Croatian population: 1880-1991 by settlements]. 1998. Priredili Jakov Gelo i sur. Zagreb: Državni zavod za statistiku Republike Hrvatske.

Nekoji rezultati popisa žiteljstva od 31. prosinca 1880: broj žiteljstva, kućanstva i stoke [Some results of thecensus of December 31, 1880: Number of population, households and livestock]. 1882. Zagreb: Kr. zemaljski statistički ured.

Oesterreichische Statistik herausgegeben von der K. K. statistischen Central-Commission LXIII. Band. 1902. Wien: Kaiserlich-königliche Hof-und Staatsdruckerei.

Oesterreichisches Statistisches Handbuch für dei im reichsrathe vertreten Königreiche und Länder K. K. Statistischen central-commission. Neunter Jahrgang 1890. 1891. Wien: Kaiserlich-königliche Hof-und Staatsdruckerei.

Statistički godišnjak kraljevina Hrvatske i Slavonije. I. 1905. [The Statistical Yearbook of the Kingdom of Croatia and Slavonia. I. 1905]. 1913. Zagreb: Tisak Kr. zemaljske tiskare.

Statistički godišnjak kraljevina Hrvatske i Slavonije. II. 1906-1910. [The Statistical Yearbook of the Kingdom of Croatia and Slavonia. II. 1906-1910]. 1917. Zagreb: Tisak Kr. zemaljske tiskare.

Statistische Ubersichten über die Bevölkerung und den Viehstand von Österreich. Nach der Zählung vom 31. October 1857. 1859. Wien: Kaiserlich-königliche Hof-und Staatsdruckerei.

\section{Electronic documents}

Državni zavod za statistiku Republike Hrvatske. Stanovništvo prema starosti i spolu po naseljima (2011) [Croatian Bureau of Statistics. Population according to age and gender by settlements (2011)] http://www.dzs.hr/Hrv/censuses/census2011/results/htm/ H01_01_03/h01_01_03_zup05.html. (retrieved 28 July 2015). 


\section{Literature}

ALLEN, Robert C. 2003. Progress and poverty in early modern Europe. Economic History Review 56/3: 403-443.

ARTUKOVIĆ, Mato. 2001. Srbi u Hrvatskoj (Khuenovo doba) [Serbs in Croatia (Khuen's period)]. Slavonski Brod: Hrvatski institut za povijest - Podružnica za povijest Slavonije, Srijema i Baranje.

BAUER, Thomas. 2011. Theory and evidence of labor migration in Europe. In Interdisciplinary Management Research VII, ed. Dražen Barković et al., 449-474. Osijek: Faculty of Economics - Postgraduate Studies Management, Hochschule Pforzheim University.

BURKE, Edmund. 1993. Razmišljanja o Francuskoj revoluciji [Reflections on the revolution in France]. Zagreb: Politička kultura.

CASTELS, Stephen, J. Mark MILLER. 2009. The age of migration: international population movements in the modern world. Basingstoke, New York: Palgrave Macmilan.

DAMJANOVIĆ, Dragan. 2013. Gradnja i opremanje varaždinske pravoslavne crkve 1884. godine [Orthodox Church in Varaždin - construction and furnishing in 1884]. Radovi Zavoda za znanstveni rad HAZU Varaždin 24: 317-340.

DESPOT, Miroslava. 1964. O privredi grada Varaždina u prvoj polovini XIX stoljeća. Prilog privrednoj historiji Hrvatske u XIX st. [On the economy of the town of Varaždin in the first half of the $19^{\text {th }}$ century. Supplement to the economic history of Croatia in the $19^{\text {th }}$ century]. In Zbornik Historijskog instituta JAZU 5, ur. Marko Kostrenčić i sur., 107-123. Zagreb: Historijski institut JAZU.

GROSS, Mirjana, Agneza SZABO. 1992. Prema hrvatskome građanskom društvu. Društveni razvoj u civilnoj Hrvatskoj i Slavoniji šezdesetih i sedamdestih godina 19. stoljeća [Towards a Croat civil society. Social development in Civil Croatia and Slavonia in 1860s and 1870s]. Zagreb: Globus.

HANÁK, Péter. 1995. Povijest Mađarske [A History of Hungary]. Zagreb: Barbat.

IVELJIĆ, Iskra. 2007. Očevi i sinovi. Privredna elita Zagreba u drugoj polovici 19. stoljeća [Fathers and sons. Economic elite in Zagreb in the second half of the 19 $9^{\text {th }}$ century]. Zagreb: Leykam international.

KALANJ, Rade. 1994. Modernost i napredak [Modernity and progress]. Zagreb: Antibarbarus.

KARAMAN, Igor. 1991. Industrijalizacija građanske Hrvatske (1800-1841) [Industrialization of Civil Croatia (1800-1841)]. Zagreb: Ahead.

KING, Russel et al. 2010. The atlas of human migration: global patterns of people on the move. Brighton: Earthscan.

LORBER, Lučka. 1999. Procesi prestrukturiranja industrije Maribora i njihov utjecaj na transformaciju prostora [The processes of industrial restructuring of Maribor and their impact on the transformation of space]. Doktorska disertacija, PMF Zagreb.

MACLEMAN, Robert A. 2014. Climate and human migration. New York: Cambridge University Press.

MADDISON, Angus. 2001. The World Economy - A Millenial Perspective. Paris: Development Centre Studies OCDE. 
MAKKAI, Béla. 2011. Migracija iz južne Mađarske preko Drave i Save krajem XIX. stoljeća [Migration to Southern Hungary across the Drava and Sava River at the end of the XIX century]. Podravina: časopis za multidisciplinarna istraživanja 19/10: 66-76.

SANDGRUBER, Roman. 1993. Wirtschaftsbürgertum und Unternehmerschaft in Österreich um 1900. In Internationales Kulturhistorisches Symposion Mogersdorf, Rogaška Slatina 1992, ur. Franc Rozman, 275-295. Maribor: Univerza Maribor.

STIPETIĆ, Vladimir. 2003. Stanovništvo i bruto domaći proizvod Hrvatske (1500-1913) u kontekstu najnovijeg rada Angusa Maddisona [Population and gross domestic product of Croatia (1500-1913) in the light of Angus Maddison's book The World Economy - A Millennial Perspective]. Anali zavoda za povijesne znanosti Hrvatske akademije znanosti i umjetnosti u Dubrovniku 41/1: 91-156.

STIPETIĆ, Vladimir. 2012. Dva stoljeća razvoja hrvatskoga gospodarstva (1820.-2005.) [Two Centuries of Croatian Economy Development (1820-2005)]. Zagreb: HAZU, Razred za društvene znanosti.

STULLI, Bernard. 1975. Prijedlozi i projekti željezničkih pruga u Hrvatskoj 1825 1863, I-II [Propositions and projects of railways in Croatia 1825 - 1863 I-II]. Zagreb: Sveučilište u Zagrebu, Institut za hrvatsku povijest.

STULLI, Bernard. 1986. Varaždinska regija u željezničkom sustavu Hrvatske (18251918) [The Varaždin region in the Croatian railway system (1825-1918)]. Historijski zbornik 39/1: 1-78.

VODOPIVEC, Peter. 2011. O industrijalizaciji Maribora in spodnje Štajerske v 19. stoletju [On the industrialization of Maribor and lower Styria in the 19th century]. Prispevki za novejšo zgodovino 51/2: 7-28.

VRANJEŠ-ŠOLJAN, Božena. 1991. Stanovništvo gradova banske Hrvatske na prijelazu stoljeća [The population of the towns of Civil Croatia at the turn of the century]. Zagreb: Školska knjiga, Stvarnost.

VRANJEŠ-ŠOLJAN, Božena. 2003. Naseljavanje Mađara u Slavoniji 1880.-1910. [Hungarian Settlement in Slavonia 1880-1910]. In: Zbornik Mire Kolar-Dimitrijević: zbornik radova povodom 70. rođendana, ur. Damir Agičić, 257-271. Zagreb: Filozofski fakultet, Odsjek za povijest.

VRANJEŠ-ŠOLJAN, Božena. 2009. Stanovništvo Banske Hrvatske. Demografska slika Banske Hrvatske u kontekstu društveno-povijesnih promjena od 1850. do 1910. [The population of Civil Croatia. The Demographic Picture of Croatia in the Context of Socio-Historic Changes 1850-1910]. Zagreb: Educa.

WERTHEIMER-BALETIĆ, Alica. 1999. Stanovništvo i razvoj [Population and development]. Zagreb: Mate d. o. o.

ZORIČIĆ, Milovan. 1896. Žiteljstvo Kraljevina Hrvatske i Slavonije po zvanju i zanimanju [The population of the Kingdom of Croatia and Slavonia by vocation and profession]. In Rad JAZU. Razredi filologičko-historički i filosofičko-juridički CXXV, 50-197. Zagreb: JAZU.

ŽIVAKOVIĆ-KERŽE, Zlata. 1996. Urbanizacija i promet grada Osijeka na prijelazu stoljeća (1868. -1918.) [The urbanization and traffic of Osijek at the turn of the century (1868 -1918)]. Osijek: Društvo za hrvatsku povjesnicu. 
ŽIVAKOVIĆ-KERŽE, Zlata. 2003. Donjodravski plovidbeni put u 19. i početkom 20. stoljeća (s posebnim odnosom države prema tom problemu) [Lower Drava navigationalway in the 19th and at the beginning of the 20th century (with a special reference to the position of the state on this problem)]. Scrinia Slavonica 3: 211-230.

ŽIVAKOVIĆ-KERŽE, Zlata. 2010. Značenje plovne rijeke Drave u razvoju grada Osijeka (Osvrt na 19. stoljeće) [The significance of the Drava navigability in the development of Osijek (in View of the 19th Century)]. Anali Zavoda za znanstveni i umjetnički rad u Osijeku 26: 75-88.

\section{Migracijska kretanja u Varaždinu u kontekstu modernizacijskih} procesa (1850. - 1918.) s posebnim osvrtom na gradove u Banskoj Hrvatskoj i Štajerskoj

U članku se kompariraju migracijska kretanja u Varaždinu u razdoblju modernizacije (1850. - 1918.) s vodećim gradovima hrvatskog (Zagreb i Osijek) i štajerskog prostora (Graz i Maribor). Propituje se snaga centraliteta urbanog prostora, odnos između prirodnog i migracijskog kretanja stanovništva te njihova implikacija na njegovu društveno-ekonomsku i etničku strukturu. Rezultati istraživanja pokazuju da su migracije na varaždinskom prostoru bile slabijeg intenziteta, što je posljedica položaja Varaždina kao modernizacijske periferije. Uzroke takvog stanja potrebno je tražiti u nametnutoj prometnoj izolaciji, nedostatnoj akumulaciji kapitala i kasnoj industrijalizaciji. Posljedice navedenog povijesnog razvoja vidljive su u suvremenim demografskim strukturama. Prva etapa modernizacije (1850. - 1918.) na srednjoeuropskom prostoru pokazala se ključnom u daljnjem razvoju procesa urbanizacije, industrijalizacije i društvene stratifikacije grada Varaždina, što se odrazilo i na migracijska kretanja koja su bila slabijeg intenziteta u odnosu na vodeće gradove hrvatskog i srednjoeuropskog prostora, uzrokujući demografsku stagnaciju vidljivu u suvremenim strukturama. Uzroke je potrebno tražiti u nemogućnosti izgradnje željezničke infrastrukture, nedostatnoj akumulaciji kapitala i kasnoj industrijalizaciji jer istraživanje pokazuje reverzibilnost društveno-ekonomskog razvoja i migracija. Dokaz tome je konjukturna etapa u razvoju Varaždina (1857. - 1869.) obilježena počecima industrijalizacije, usponom urbanizacije, imigracijom (udio „nezavičajnih“u strukturi stanovništva iznosio je 26,33\%) i povećanjem ukupnog stanovništva za 18,32\%, nakon čega je uslijedilo razdoblje stagnacije gospodarstva (1869. - 1880.) što se odrazilo na negativna demografska kretanja (smanjenje stanovništva za 2,87\%). U narednim desetljećima zabilježeni su pozitivni, ali vrlo usporeni demografski procesi s niskom razinom mobilnosti stanovništva rekonstruiranom na temelju podataka o zavičajnosti i jezika: visoki udjeli rođenih u Varaždinu i govornika hrvatskog jezika kao materinskog s tendencijom njihovag povećanja u ukupnoj strukturi 
stanovništva. Odnos između prirodnog i migracijskog kretatanja varaždinskog stanovništva u prvom desetljeću 20. stoljeća pokazuje da je njegovo povećanje posljedica isključivo imigracije koja, zbog niskog intenziteta, nije mogla osigurati značajan demografski rast (u razdoblju između 1900. i 1910. varaždinsko stanovništvo povećalo se za skromnih 5,7\%). Analiza dobne i spolne strukture stanovništva pokazuje smanjenje muške populacije dobne skupine od 25. do 29. godine (radno sposobno stanovništvo) koja je uključena u emigracijska kretanja, usmjerena prvenstveno prema ostatku nacionalnog, odnosno srednjoeuropskog prostora. Usporedba statističkih podataka o iseljavanju iz Varaždinske županije i grada Varaždina pokazuje da su emigracijski procesi u Županiji bili znatno jačeg intenziteta i različitog usmjerenja, što je posljedica agrarne krize i s njome povezane prenapučenosti koja je nastala uslijed dioba seljačkih zadruga. Očigledno je da grad Varaždin i ostatak nacionalnog prostora nisu bili u stanju absorbirati siromašan sloj seljaštva sjeverozapadne Hrvatske koji je iseljavao, prvenstveno u sjevernu Ameriku.

Ključne riječi: migracije, stanovništvo, Varaždin, modernizacija, urbanizacija, industrijalizacija.

Key words: migrations, population, Varaždin, modernization, urbanization, industrialization.

Ivančica Jež Ludbreška 125, Globočec 42230 Ludbreg ivancicajez@gmail.com 


\section{FILOZOFSKI FAKULTET SVEUČILIŠTA U ZAGREBU \\ ZAVOD ZA HRVATSKU POVIJEST \\ INSTITUTE OF CROATIAN HISTORY \\ INSTITUT FÜR KROATISCHE GESCHICHTE}

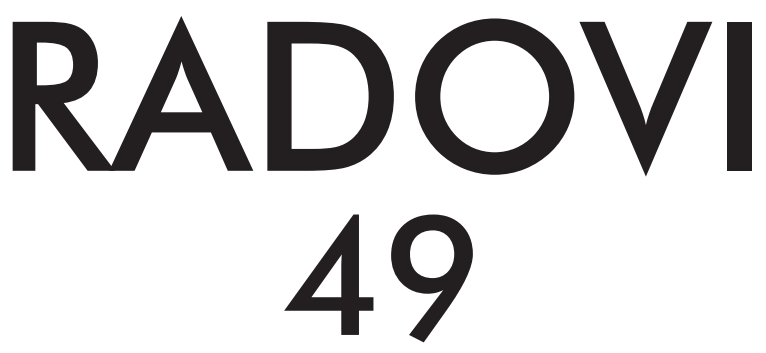

ZAVOD ZA HRVATSKU POVIJEST

FILOZOFSKOGA FAKULTETA SVEUČILIŠTA U ZAGREBU

\section{FF press}

ZAGREB 2017. 


\title{
RADOVI ZAVODA ZA HRVATSKU POVIJEST FILOZOFSKOGA FAKULTETA SVEUČILIŠTA U ZAGREBU \\ Knjiga 49
}

\author{
Izdavač / Publisher \\ Zavod za hrvatsku povijest \\ Filozofskoga fakulteta Sveučilišta u Zagrebu \\ FF-press \\ Za izdavača / For Publisher \\ Vesna Vlahović Štetić \\ Glavni urednik / Editor-in-Chief \\ Hrvoje Gračanin \\ Izvršna urednica / Executive Editor \\ Inga Vilogorac Brčić \\ Uredništvo / Editorial Board
}

Bruna Kuntić-Makvić (stara povijest/ancient history), Zrinka Nikolić Jakus (srednji vijek/

medieval history), Hrvoje Petrić (rani novi vijek/early modern history), Željko Holjevac (moderna povijest/modern history), Tvrtko Jakovina (suvremena povijest/contemporary history),

Silvija Pisk (mikrohistorija i zavičajna povijest/microhistory and local history),

Zrinka Blažević (teorija i metodologija povijesti/theory and methodology of history)

Međunarodno uredničko vijeće / International Editorial Council

Denis Alimov (Sankt Peterburg), Živko Andrijašević (Nikšić), Csaba Békés (Budapest), Rajko Bratož (Ljubljana), Snježana Buzov (Columbus, Ohio), Svetlozar Eldarov (Sofija), Toni Filiposki

(Skopje), Aleksandar Fotić (Beograd), Vladan Gavrilović (Novi Sad), Alojz Ivanišević (Wien),

Egidio Ivetić (Padova), Husnija Kamberović (Sarajevo), Karl Kaser (Graz),

Irina Ognyanova (Sofija), Géza Pálffy (Budapest), Ioan-Aurel Pop (Cluj),

Nade Proeva (Skopje), Alexios Savvides (Kalamata), Vlada Stanković (Beograd),

Ludwig Steindorff (Kiel), Peter Štih (Ljubljana)

Izvršni urednik za tuzemnu i inozemnu razmjenu /

Executive Editor for Publications Exchange

Martin Previšić

Tajnik uredništva / Editorial Board Assistant

Dejan Zadro

Adresa uredništva/Editorial Board address

Zavod za hrvatsku povijest, Filozofski fakultet Zagreb, Ivana Lučića 3, HR-10 000, Zagreb

Tel. ++385 (0)1 6120 150, 6120 158, faks ++385 (0)1 6156879

Časopis izlazi jedanput godišnje / The Journal is published once a year

Časopis je u digitalnom obliku dostupan na / The Journal in digital form is accessible at

Portal znanstvenih časopisa Republike Hrvatske „Hrčak“ http://hrcak.srce.hr/radovi-zhp

Financijska potpora za tisak časopisa / The Journal is published with the support by Ministarstvo znanosti, obrazovanja i športa Republike Hrvatske

Časopis je indeksiran u sljedećim bazama / The Journal is indexed in the following databases: Directory of Open Access Journals, EBSCO, SCOPUS, ERIH PLUS, Emerging Sources Citation Index - Web of Science 


\title{
Naslovna stranica / Title page by
}

Iva Mandić

\section{Grafičko oblikovanje i računalni slog / Graphic design and layout Marko Maraković}

\author{
Lektura / Language editors \\ Samanta Paronić (hrvatski / Croatian) \\ Dražen Nemet (engleski / English) \\ Tisak / Printed by \\ Tiskara Zelina d. d., Sveti Ivan Zelina \\ Naklada / Issued \\ 250 primjeraka / 250 copies
}

Časopis je u digitalnom obliku dostupan na Portalu znanstvenih časopisa Republike Hrvatske „Hrčak“ http://hrcak.srce.hr/radovi-zhp

The Journal is accessible in digital form at the Hrcak-Portal of scientific journals of Croatia http://hrcak.srce.hr/radovi-zhp 